\title{
壁付け太陽熱集熱パネルによる供給熱量計算方法 \\ CALCULATION METHOD OF SUPPLY HEAT QUANTITY FOR A SOLAR HEATING PANEL MOUNTED ON EXTERNAL WALL
}

\author{
松永 潤一郎*1, 福島 明*2, 田島昌 樹*3 \\ Junichiro MATSUNAGA, Akira FUKUSHIMA and Masaki TAJIMA
}

\begin{abstract}
Pneumatic solar collector systems have a certain advantage of conversion efficiency of $40 \%$ to $60 \%$ and less long-term failure compared with liquid types. However, according to previous studies, pneumatic solar heating systems require large power input for air supplying and sometimes provide overheating and overdrying. In this paper, a method for predicting the heat collection amount for energysaving design utilizing a self-supporting solar heat collection system, which does not require an external power source employing photovoltaic panels and whose supplying airflow rate is smaller than 24 hours ventilation systems, is presented, and is practicality clarified by comparison with experiments and actual measurements.
\end{abstract}

Keywords : Air-based Solar Collector, ventilation, heating, Separation of global irradiance, Simulation 空気式太陽熱集熱，換気，暖房，直散分離，シミュレーション

\section{1.はじめに}

再生可能エネルギーである太陽エネルギーの利用において、熱を そのまま利用する手法はエネルギー変換効率が 40 ～ $60 \%$ と太陽光 発電の $10 \sim 15 \%$ より高く 1 )、給湯や暖房といった熱の利用にバラン スよく検討する事でより効率良く省エネ効果を発揮することが可能 となる。この太陽エネルギーの熱利用の手法として液体式と空気式 の 2 種類があるが、空気式は液体式の場合に見られる「配管の劣化 等による液体が漏れる 2) といった長期的に不具合が発生するリスク が少ない」といったメリットがある。今まで空気式における研究で は、屋根空気集熱式ソーラーシステムの研究が多い。しかし、空気 式の屋根集熱方式の場合、温暖地版 自立循環型住宅への設計ガイ ドライン」3）屋根空気集熱式ソーラーシステムの計画において、集 熱量の確保をするため送風ファンは外気導入量を $8 \mathrm{~m}^{3} / \mathrm{min}$ $\left(480 \mathrm{~m}^{3} / \mathrm{h} 、 24\right.$ 時間換気として設定している $160 \mathrm{~m}^{3} / \mathrm{h}$ の 3 倍 $)$ 以上 の能力で使用する事が推奨指定されているように、熱容量の小さい 空気を利用し効率よく暖房エネルギーとして利用するためには、自 立循環型住宅の一般モデルで 24 時間換気システムとして必要な換 気回数 0.5 回/h と比べ 1.5 回/h 以上と大きな風量が必要となり、送 風動力による一次エネルギー消費が創エネされた熱エネルギーを相 当分相殺してしまう点、集熱量と蓄熱によるタイムシフト効果と暖

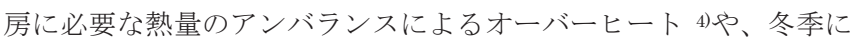
集熱の為に乾燥した外気を 24 時間換気の必要量に対して過大に取 り込むことにより引き起こされる過乾燥発生の可能性といった課題
がある。

このように課題はあるが、太陽エネルギーの活用手法として空気 式太陽熱集熱は利点が多く、その課題を克服するシステムが求めら れている。本研究で対象とする壁付け空気式太陽熱集熱パネルは、 外部電源を必要としない自立型として開発されたものである。24 時間換気の風量以下で運用することで必要ファン動力を抑え、内蔵 された太陽光発電パネルで発電した電気で送風動力を賄える完全自 立型のシステムとなっている。制御を含めて極めて簡素な設備とし、 初期投資を押さえて暖房負荷低減による設備投資対効果を確保しよ うとするものである。主に使用する冬期は、太陽高度が低い事から 壁設置で太陽熱利用が可能で、集熱空気を直接屋内に取り込める事 もシステムの低廉化に寄与している。また、従来のような過剩な換 気による冬季の過乾燥を引き起こす可能性も少ない。このように設 備投資対効果の高い装置と考えらえるが、地域の気候条件に応じた 集熱効果の予測手法が確立しておらず、その効果を定量的に示すこ とができていない。

本研究は、当該太陽熱集熱パネルを用いた省エネルギー設計の為 の太陽エネルギーの利用効果を定量的に予測する手法を確立するこ とを目的とし、基本的な集熱性能や送風性能の実験により評価を行 うとともに、一般的に入手可能な株式会社気象データシステムが頒 布している「拡張アメダス気象データ」(以下 EA気象データ)の全 天日射量を用いて全国各地の集熱量予測が出来るよう直散分離が容 易に出来る手法を構築した。また、実住宅での実測結果から効果予 
測計算との比較をして実用性を明らかにするとともに、全国の代表 的な地域における集熱量の試算を行った。

\section{2. 既往の研究}

これまでも様々な空気式太陽熱集熱に関する研究が行われてきた。 壁式集熱方式では、宮沢ら5) が壁式集熱パネルの性能試験を行い集 熱板の種類、日射量・給気量 - 日射吸収率・外部風速・面積等様々 な条件の違いによる集熱性能の検証を行い、図子ら ${ }^{6)}$ 及び小金井ら 7)は壁式集熱パネルの集熱性能の実測調査を行っている。屋根集熱 方式では、北野ら 8) 9)が設計条件（暖房負荷、室設定温度、コレクタ 一の特性、蓄熱層の種類、日射量や集熱設定温度等）からコレクタ 一面積や蓄熱槽容量及び集熱時放熱時の風量の最大值を求める太陽 熱暖房システムの簡易設計法の検討や、中村ら 10) は、方位や建物仕 様、熱容量、蓄熱部位や集熱部の長さ・傾斜角、搬送経路や運転方 法等様々な要素を変数とするシミュレーションにより温熱環境の違 いを検討し設計指針の提案を行っている。また、太陽熱集熱装置の 性能解析として、藤岡ら ${ }^{11}$ が空気集熱式太陽熱利用システムの実測 による集熱特性把握を行い、宇田川ら 12) は屋根一体型太陽熱集熱暖 房・給湯の予測としてシミュレーションプログラムを構築している が、本研究のようにシミュレーション構築と実測による検証がされ た事例はない。そして、岩田ら $\left.{ }^{13}\right)$ は実測による温度状況の把握を行 っており、他にも温度状況などの実測事例は多数報告があるものの、 いずれの研究も本研究の目的とする、一般に入手が容易な「EA 気 象データ」の全天日射量を使用して、簡易に集熱量試算を可能とす る実用的なシミュレーション手法はほとんど無い。

\section{3. 対象システムの概要}

本研究で検討した太陽熱集熱パネルは、外気を太陽熱で加温して 室内に導入を行うため、換気によって発生する暖房負荷を減らす事 が可能で、室内環境の向上と暖房負荷の低減を外部からのエネルギ 一入力なしに行う技術であり、一次エネルギー消費量削減の観点か ら今後の普及が期待される。また、外気が直接導入される排気型換 気システムとの組合せにおいては、集熱パネルより供給される給気 分が外気の予熱として作用するので相性がよい。
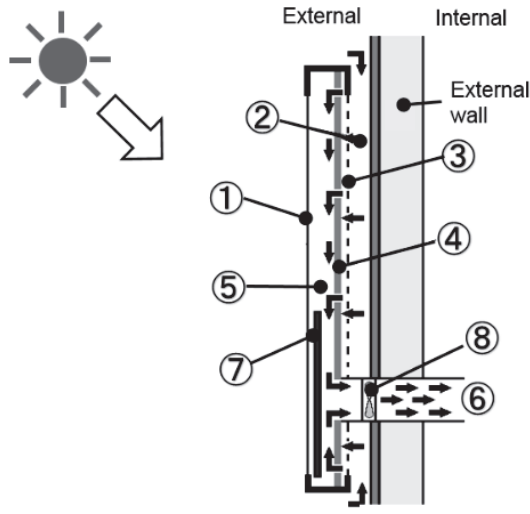

(1)Polycarbonate

(4)Felt

(7)P.V.
(2)Air inlet

(5)Air space

(8) Supply fan
(3) Perforated plate

(6) Heated supply air
Fig.1 Outline of the wall mounted solar heat collection panel
Table1 Technical deta Spec of the w all mounted solar heat colletion panel

\begin{tabular}{|l|l|}
\hline Dimens ion $[\mathrm{mm}]$ & $1974 \times 704 \times 55$ \\
\hline Weight $[\mathrm{kg}]$ & 14 \\
\hline Air flow $\left[\mathrm{m}^{3} / \mathrm{h}\right]$ & $60 \sim 110$ \\
\hline Ventilator - pow er consumption $[\mathrm{W}]$ & 4 \\
\hline Solar cell - pow er generation [W] & 12 \\
\hline
\end{tabular}

検討対象としたシステムの概要を Fig. 1 にシステムの性能を Teble1 示す。（丸囲みの数字は図示される部位を指す）表面はプラ スチック製の断熱を兼ねた中空

板になっている透明カバー(1)で、裏側(2)は外気を取り込む多数の小 孔が空いている板(3)と断熱と集熱を兼ねたフェルト(4)になってお り、その間が中空層(5)として構成されたパネルである。太陽光で温 められたフェルト(4)の裏側から空気が吸入され、中空層を通過する ことで空気を暖めながら室内取り入口から室内に加温された空気(6 が供給される。空気の搬送には装置中に設置された太陽光発電パネ ル(7)の発電により稼働するファン（8)を用いている。装置の利用は冬 期を想定しており、日射取得を考慮して南側外壁面に設置する。

\section{4. 集熱量計算方法の検討}

\section{1 集熱量の微分方程式}

本装置の集熱量予測を行うため、中空層(5)における熱収支の式を (1)に示す。左辺の $\bar{M} は(2)$ に示す相当熱容量と定義した。この相当 熱容量は、ケーシング内空気の熱容量と周囲部材の熱容量の一部を 加えたものである。 $M_{B}$ :「周囲部材の熱容量の一部」については実 測値との比較から $5057 \mathrm{~J} / \mathrm{K}$ (注) と同定した。

これらの式に数值を入力寸ることで供給空気の温度の算定が可能 となる。

$\bar{M} \frac{d T}{d t}=U_{F} A_{F}\left(T_{0}-T i\right)+U_{B} A_{B}\left(T_{0}-T i\right)+0.348 Q\left(T_{0}-T i\right)+J_{R} A_{F}$

$\overline{\mathrm{M}}=\mathrm{M}_{\mathrm{A}}+\mathrm{M}_{\mathrm{B}}$

$\bar{M}:$ 相当熱容量 $[\mathrm{J} / \mathrm{K}]$

$M_{A}: c \rho V$ ケーシング内空気の熱容量 $[\mathrm{J} / \mathrm{K}]$

$M_{B}:$ 周囲部材の熱容量の一部 $[\mathrm{J} / \mathrm{K}]$

$U$ : 熱貫流率 $\left[\mathrm{W} / \mathrm{m}^{2} \mathrm{~K}\right]$

(サフィックスは部位を表す。F:集熱部、B:ケーシング)

$A$ : 面積 $\left[\mathrm{m}^{2}\right]$

（サフィックスは部位を表す。F:集熱部、B:ケーシング）

$Q$ : 風量 $\left[\mathrm{m}^{3} / \mathrm{h}\right]$

$T$ : 温度 $\left[{ }^{\circ} \mathrm{C}\right]$ (サフィックス $\mathrm{o}$ は外気、 $\mathrm{i}$ は本体中空層)

$J_{R}$ : パネル内に透過する日射量 $\left[\mathrm{W} / \mathrm{m}^{2}\right]$

$\mathrm{C}:$ 空気比熱 $[\mathrm{J} / \mathrm{kg} \cdot \mathrm{K}]$

$\rho:$ 空気密度 $\left[\mathrm{kg} / \mathrm{m}^{3}\right]$

$V:$ 容積 $\left[\mathrm{m}^{3}\right]$

$t:$ 時間 $[\mathrm{h}]$ 
4. 2 パネルに入射する日射量と風量の関係

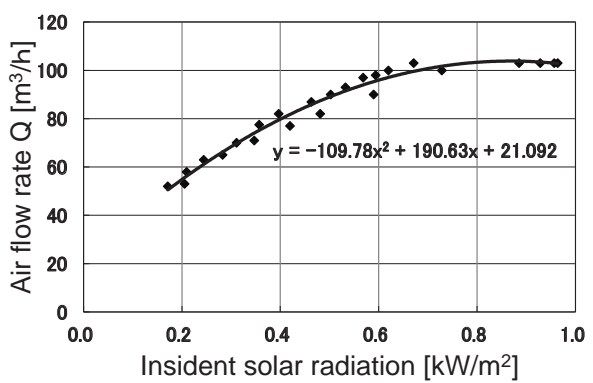

Fig.2 Incident solar radiation and air flow rate of the panel

本機器は内蔵された太陽光発電パネルで発電した電気で送風ファ ンが運転されるが、発電量が日射量によって変動しそれに伴いファ ン風量も一定ではない。そこで予め入射日射量とファン風量の関係 性を事前に実測した結果をFig. 2 に示す。シミュレーション計算に おける $Q$ : 風量についてはこの結果から得られた近似式を用い、風 量の算定を行った。

\section{3 全天日射量の直散分離}

直散分離に関する研究は数多く存在し、直散分離の手法として Nagata モデルが有名で、住宅の次世代省エネルギー基準の適合判 定に使用できる $\mathrm{SMASH}^{14}$ ) (多数室の動的熱負荷計算プログラム) でも使用されているが、快晴時を前提としている為、本研究の様々 な気象条件での集熱量を試算するためには適さない。そこで、本研 究では、アメダス気象データを開発している㑣気象データシステム が発行している技術解説「直散分離と斜面日射量の計算」15) を参考 とした。EA 気象データに収録されている日射量は、気象台で観測 された水平面全天日射量, または日照時間等から推定された水平面 全天日射量である。その全天日射量を直散分離する手法として、 EADataNavi に付属している直散分離プログラム SplitG では、 Nagata モデル、Udagawa モデル、Erbs モデル、Watanabe モデ ル、Perez モデルの 5 つのモデルが採用されている。この 5 モデル について $1 / 2$ 開口角が $2.5^{\circ}$ の自記直達日射計による直達日射量を、

RMSE (Root Mean Square Error) と MBE(Mean Bias Error)を評 価指標に用い推定誤差の比較を行った結果、Perez モデルが開口角 $2.5^{\circ}$ の直達日射計よる法線面直達日射量の観測值に最もよく一致し ていることから SplitG では、Perez モデルが推奨法として位置づけ られている。しかし Perez モデルで計算を行うためには、計算に必 要な係数の算出過程が公開されておらず、一般に設計評価に用いる には課題が多い。

\section{3.1 新しい直散分離モデルの検討}

そこで容易に直散分離が行えるように、Perez モデルの結果に近 づくように検討を行い、本研究では新しいモデルとして式(3) (6)を 作成した。

$I_{b}=I_{O} P^{\frac{1}{\sin h}}$

$P=\left\{\frac{K_{t}-0.27}{0.73}\right\} \sin h$
$K_{t}=\frac{I_{G}}{I_{O} \sin h}$

$I_{d}=I_{G}-I_{b} \cdot \sin h$

$I_{G}:$ 水平面全天日射量 $\left[\mathrm{W} / \mathrm{m}^{2}\right]$

$I_{b}$ : 法線面直達日射量 $\left[\mathrm{W} / \mathrm{m}^{2}\right]$

$I_{d}:$ 水平面天空日射量 $\left[\mathrm{W} / \mathrm{m}^{2}\right]$

$h:$ 太陽高度 $[\mathrm{o}]$

$P$ : 大気透過率 $[-]$

$K_{t}$ : 晴天指数 $[-]$

$I_{O}:$ 太陽定数 $1367 \mathrm{~W} / \mathrm{m}^{2}$

\section{3. 2 本研究モデルと既往モデルとの比較}

既往モデルを代表して、SMASH で使用されている Nagata モデ ルと、SplitG で推奨法として位置づけられている Perez モデルの 2 モデルを比較対象とし、2000 年版標準年 $\mathrm{EA}$ 気象データを用いて直 散分離を行い本研究モデルとの比較を行った。比較は年間を通して 検討を行ったが、例として $1 / 1 \sim 1 / 10$ の 10 日間の結果について次 に示す。

\section{1）大気透過率}

比較の結果を Fig. 3 に、相関関係を Fig. 4 に示す。本研究モデル と比較して Nagata モデルは最高值で高くなっているおり、Perez モデルは透過率が低い時に低めで推移している。本研究モデルはそ の中間辺りで推移しており相関関係が確認できる。

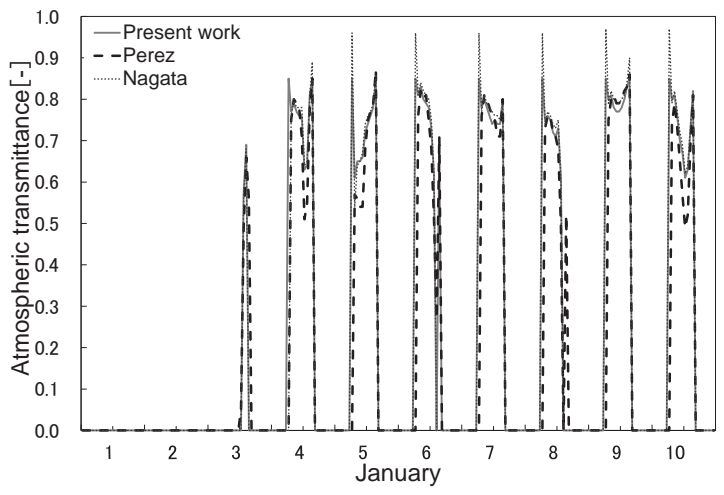

Fig.3 Atmospheric transmittance

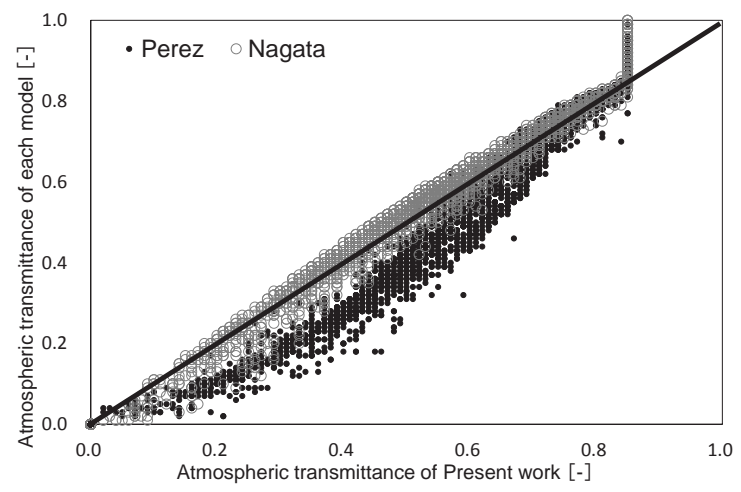

Fig.4 Atmospheric transmittance of present work and other models 


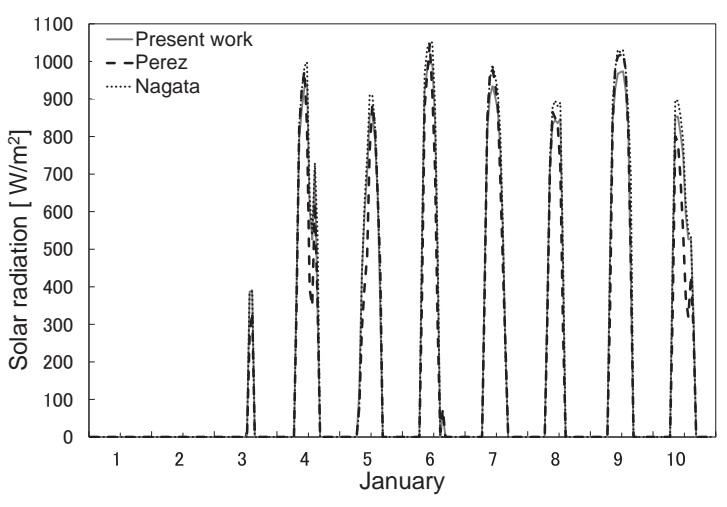

Fig.5 Normal direct solar radiation

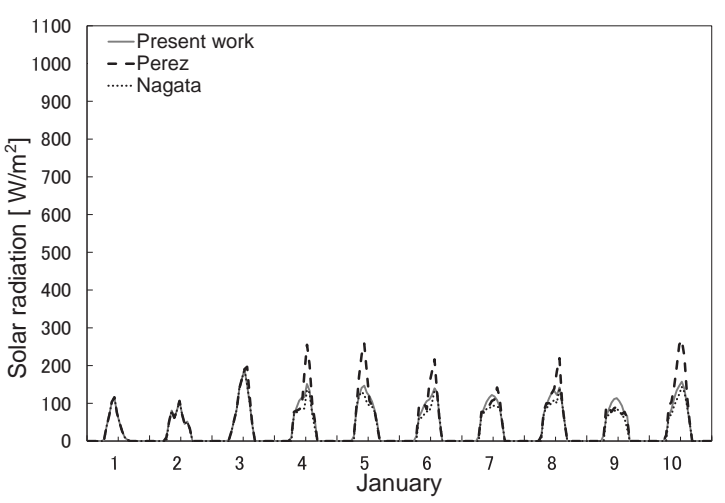

Fig. 6 Horizontal sky solar radiation

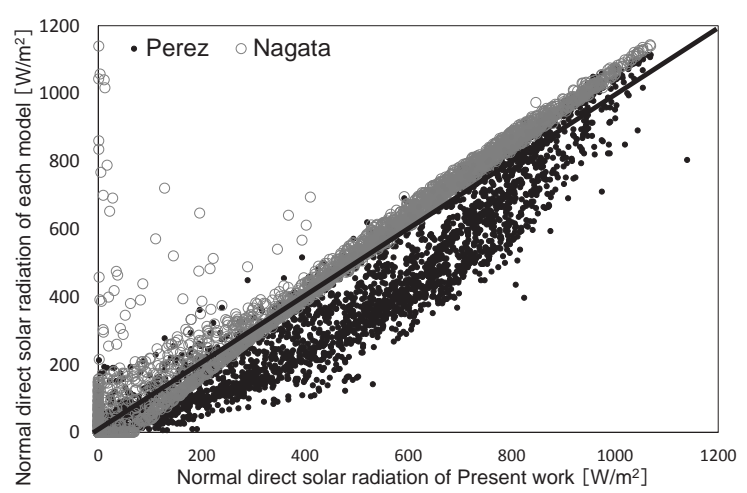

Fig.7 Normal direct solar radiation of present work and other models

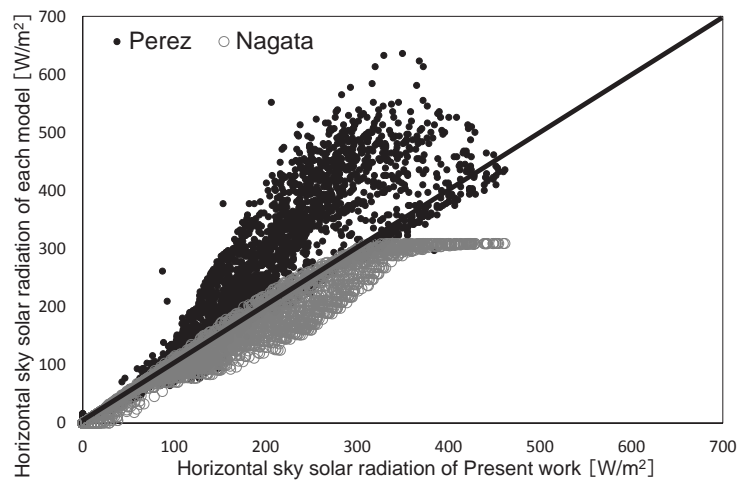

Fig. 8 Horizontal sky solar radiation of present work and other models

\section{2）法線面直達日射量と水平面天空日射量}

法線面直達日射量の比較を Fig. 5、相関関係を Fig. 7 に水平面天空 日射量の比較を Fig. 6、相関関係を Fig. 8 に示す。法線面直達日射 量で、本研究モデルに対し他 2 モデルとも日射量が多い時には若干 高く、日射量が少なくなると Perez モデルは本研究モデルより低め になっている。しかし、水平面天空日射量では Perez モデルが本研 究モデルに対し最大值が大きく Nagata モデルは法線面直達日射量 とは逆に水平面天空日射量では小さくなっている。

Fig. 7 及び Fig. 8 の相関から Perez モデルと Nagata モデルの直散 分離の特性が反対の特性を持っていることを示しており、本研究モ デルは概ねその中間值を示した。

\section{3）南鉛直面の入射日射量}

直散分離されたデータを使い、南鉛直面の入射日射量を試算した 結果を Fig. 9 に示す。昼の最大值で Perez モデル、Nagata モデル、 本研究モデルの順でやや高くなっているが、その差は僅かで、集熱 量計算に使用する入射日射量の試算にあたっては Fig. 10 のように 両モデルとも良好な一致がみられた。

以上の結果から、本研究モデルが既往のモデルと比較して、十分 高い近似值が得られることが確認できた。

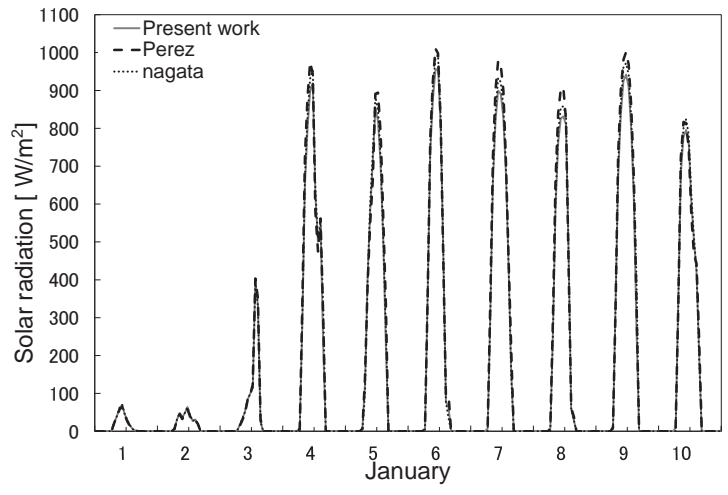

Fig.9 Incident solar radiation on facing south vertical

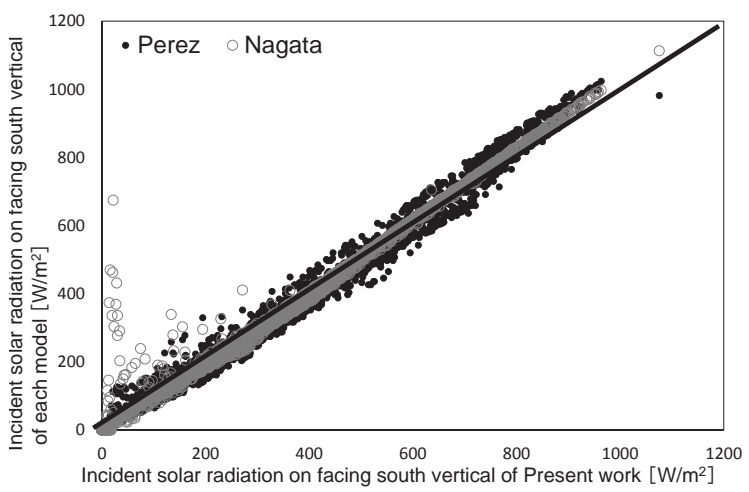

Fig.10 Incident solar radiation on facing south vertical of present work and other models 


\section{4 透過日射量の算定法}

\section{4.1 日射量を求める基本式}

$J_{R}=I_{b} \tau_{b}+I_{f} \tau_{f}$

$I_{f}=I_{d}+\frac{1-\cos \theta}{2} \rho_{g}\left(I_{b} \sin h+I_{d}\right)$

$I_{b}:$ 法線面直達日射量 $\left[\mathrm{W} / \mathrm{m}^{2}\right]$

$\rho_{g}:$ 水平地表面のアルベード $[-]$

$I_{f}:$ 拡散日射量 $\left[\mathrm{W} / \mathrm{m}^{2}\right]$

$\tau_{b}:$ 直達日射透過率 $[-]$

$\tau_{f}:$ 拡散日射透過率 $[-]$

$I_{d}:$ 水平面天空日射量 $\left[\mathrm{W} / \mathrm{m}^{2}\right]$

$\theta:$ パネルの設置角度 [radian]

集熱パネル表面から透過する日射量は、直散分離したあとの直達 成分と天空成分から、(8)式で拡散日射量を求め、直達日射量の透 過率と拡散日射の透過率を求めて、(7)式で透過日射量を求める。

\section{4.2 パネルヘの日射の透過率の算定}

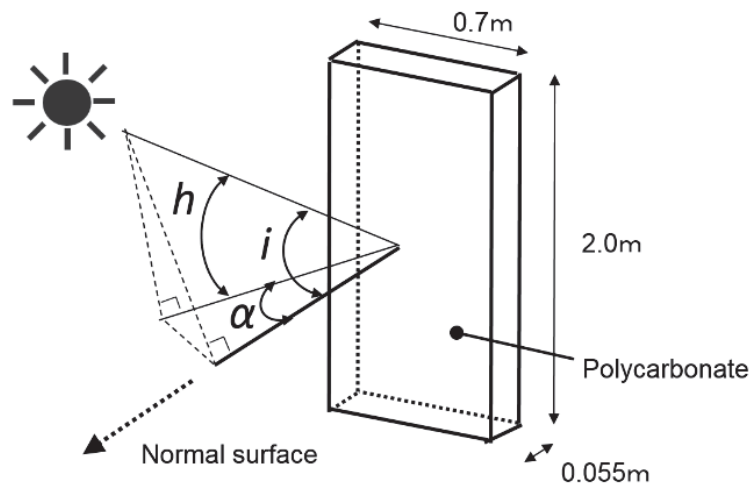

$h:$ Solar altitude $\left.{ }^{0}\right]$

$\alpha$ : Solar azimuth $\left[^{0}\right]$

$i$ : Incident angle $\left.{ }^{0}\right]$

Fig.11 Direct solar radiation solar azimuth

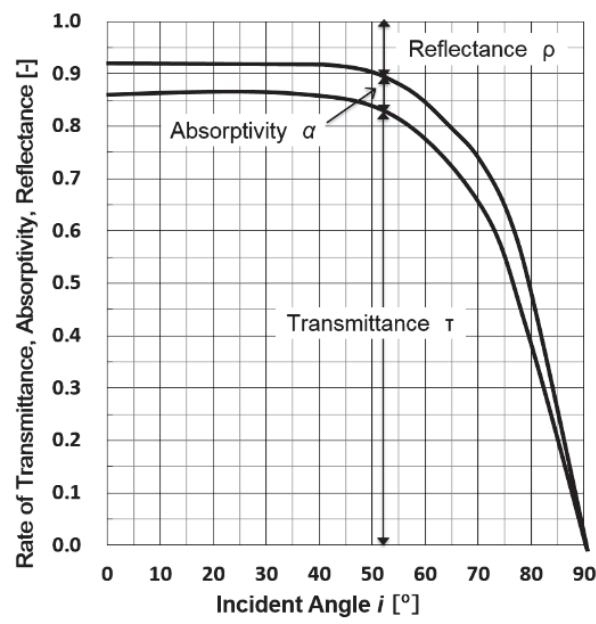

Fig.12 Incident angle and solar transmittance of $3 \mathrm{~mm}$ glass 文献 17) から作成
直達日射の透過日射量は入射角によって時々刻々と変化する。透 過率 $\tau_{b}$ はFig. 11 の入射角と透過率との関係から求めた。今回の壁付 け太陽熱集熱パネルには日射取得面にポリカーボネイトが使用され ているが、その值が不明なため直達日射の透過率 $\tau_{b}$ についは Fig. 12 の $3 \mathrm{~mm}$ のガラスの入射角と透過率の関係の值 16 ) を用い、ペ アガラス相当に換算し総合透過率として計算し、実測に合うように 最小二乗法で係数を求めた。なお、拡散日射透過率 $\tau_{f}$ にいては、 $60^{\circ}$ の時の值 $\left.{ }^{17}\right)$ を用いて計算を行った。

\section{5. 計算と実測の比較}

\section{1 集熱パネル単体との比較}

前章の理論に基づき、理論值と実測の比較を行い、理論值の再現 性について確認を行った。壁付け太陽熱集熱パネルをPhoto1 及び 2 のように設置してパネル面への鉛直日射量、各点における温度及び 吹出し温度を測定した。実験概要についてFig. 13 に示し、Table2 に 示した計測機器及び測定間隔で測定を行った。今回の日射量の測定 は瞬時值の測定となるため、測定間隔を大きくしてしまうとその瞬 間毎の雲や影の影響を受けてしまう。その影響を最小限にするため に測定間隔を 1 秒とした。

測定を行った中から代表日として 2011 年 2 月 16 日の測定值と計 算値の結果をFig. 14 に、相関関係を Fig. 15 に示す。Fig. 15 から計 算値と測定值がほぼ等しい関係となり、本理論式で推定集熱量が再 現できる事が確認できた。
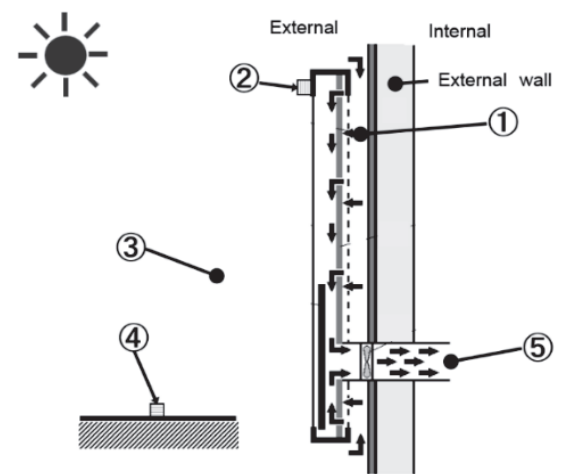

(1) Inlet air temperature

(2) Vertical incident solar radiation

(3) Outside air temperature

(4)Horizontal sky solar radiation

(5) Supply air temperature

Fig.13 Outline of measurement

Table2 Outline of experiment

\begin{tabular}{|l|l|}
\hline Date & 16th.Feb.2011 \\
\hline Location & Nerima-ku Tokyo \\
\hline Installation azimuth & Due south \\
\hline Solar radiation & $\begin{array}{l}\text { Pyrheliometer PCM-01 } \\
\text { (Made by Prede) }\end{array}$ \\
\hline Temperature & $\begin{array}{l}\text { T type thermocouple } \\
+ \text { THERMIC2300A }\end{array}$ \\
\hline Measurement interval & $1 \mathrm{sec}$ \\
\hline
\end{tabular}




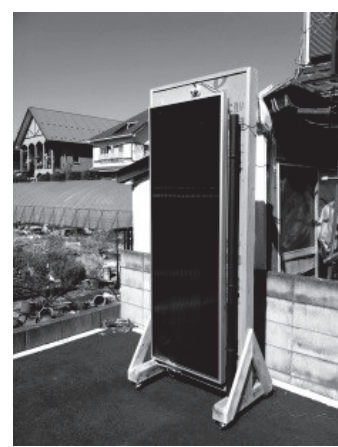

Photo1 Experimental device (external side)

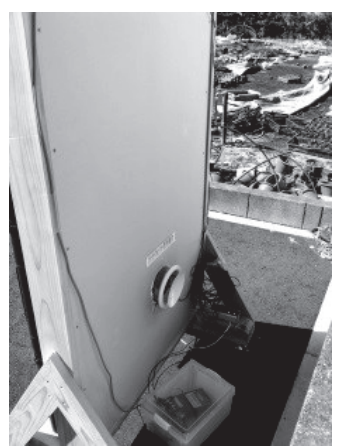

Photo2 Experimental device (internal side)

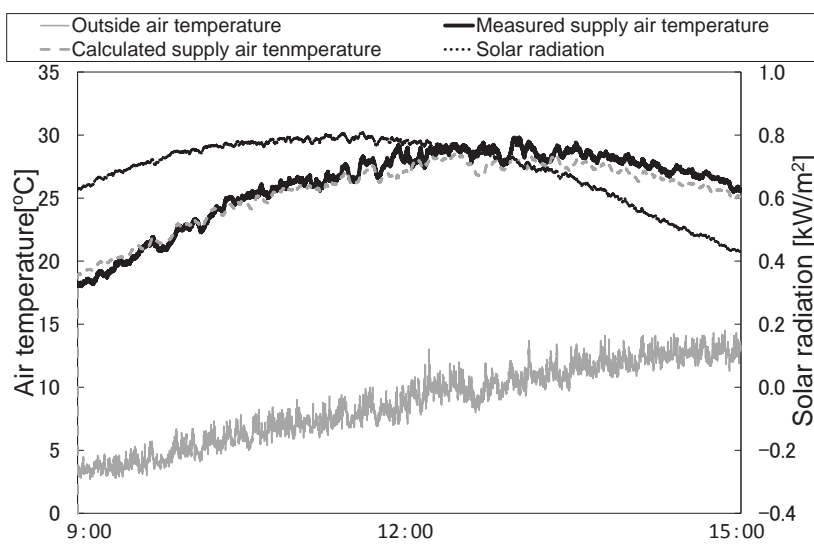

Fig.14 Measured and calculated Supply air temperature(16th.Feb.2011)

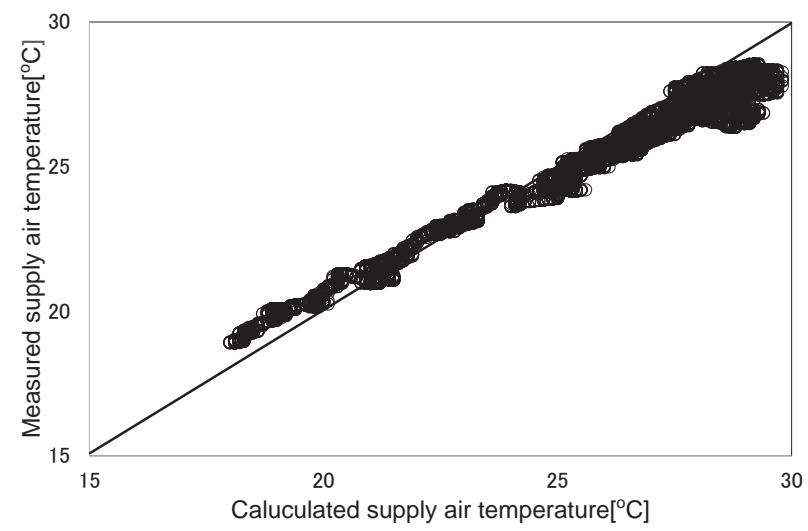

Fig.15 Measured and calculated Supply air temperature

(16th.Feb.2011)

\section{2 実棟による比較}

北海道千歳市に当システムを導入した住宅について測定を行った 事例を示す。対象住宅はPhoto3に示したもので、建物概要をTable3、 測定概要を Table4 に示す。壁付け太陽熱集熱パネルの風量につい ては、Fig. 2 より求め、全天日射量が分かれば集熱量の予測が可能 となる事から、室内吹き出し温度の計算值と実測值の比較により検 証が可能となる。

代表日の理論計算值と実測值の吹出し空気温度の変動を Fig. 16 に 示す。この測定で供給空気温度の最高值は外気温度 $+35^{\circ} \mathrm{C}$ (外気温 度が $0{ }^{\circ} \mathrm{C}$ なで吹出し温度も約 $\left.35^{\circ} \mathrm{C}\right)$ であり、日射量に応じて給
気温度が上昇していることも確認できた。また Fig. 17 から供給温 度の理論值と実測值はよく一致しており、実住宅においても理論式 が活用可能なことも確認できた。

Table3 Overview of measured housing

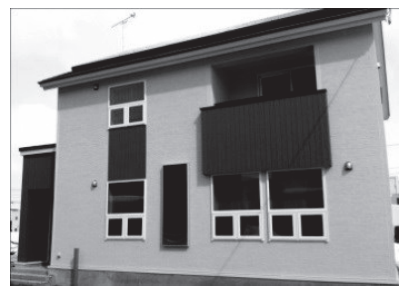

\begin{tabular}{|l|l|}
\hline Completion date & Mar.2011 \\
\hline Location & $\begin{array}{l}\text { Chitose City } \\
\text { Hokkaido }\end{array}$ \\
\hline Flor area & $129.13 \mathrm{~m}^{2}$ \\
\hline $\begin{array}{l}\text { Ventilation } \\
\text { system }\end{array}$ & Exhaust only \\
\hline
\end{tabular}

Photo3 Measured housing

Table4 Measurement items and instruments

\begin{tabular}{|l|l|}
\hline Date & 1th.Dec.2012 \\
\hline Sola radiation & Pyrheliometer PCM-01(Made by Prede) \\
\hline Temperature & T type thermocouple + THERMIC2300A \\
\hline Measurement interval & 10min \\
\hline
\end{tabular}

-- Measured supply air temperature -Calculated supply air temperature .... Outside air temperature J MA

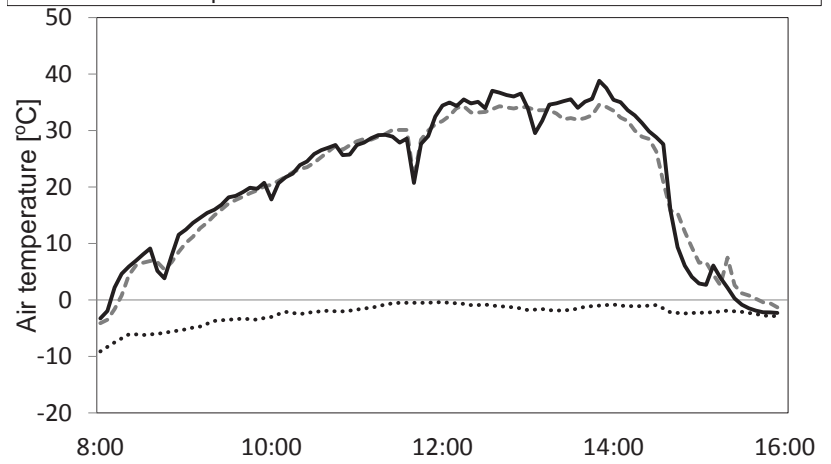

Fig.16 Measured and calculated supply air temperature in Chitose City of 1st.Dec.2012

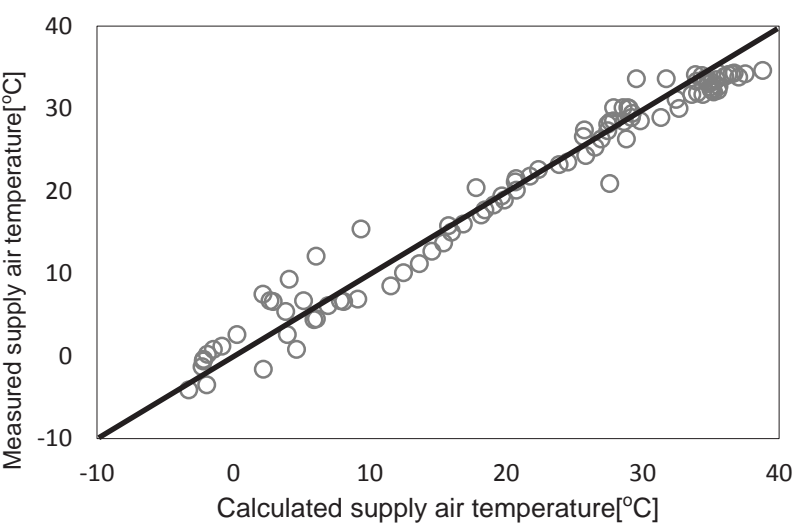

Fig.17 Measured and calculated supply air temperature in Chitose City 


\section{6. 年間取得熱量の計算}

前述の理論計算に基づき全国 18 都市における期間取得熱量につ いて計算を行った結果をFig. 18 に示す。パネルへの入射日射量に ついては、気象庁の全天日射量から、本研究モデルを用いて直散分 離し算定した。なお装置の利用可能期間を 10 月〜 5 月と設定した。 年間日射量が多い長野で約 $650 \mathrm{kWh}$ 、最も少ない秋田でも $420 \mathrm{kWh}$

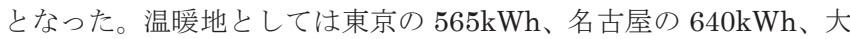
阪の $553 \mathrm{kWh}$ 、蒸暑地域としては宮崎における $649 \mathrm{kWh}$ であった。

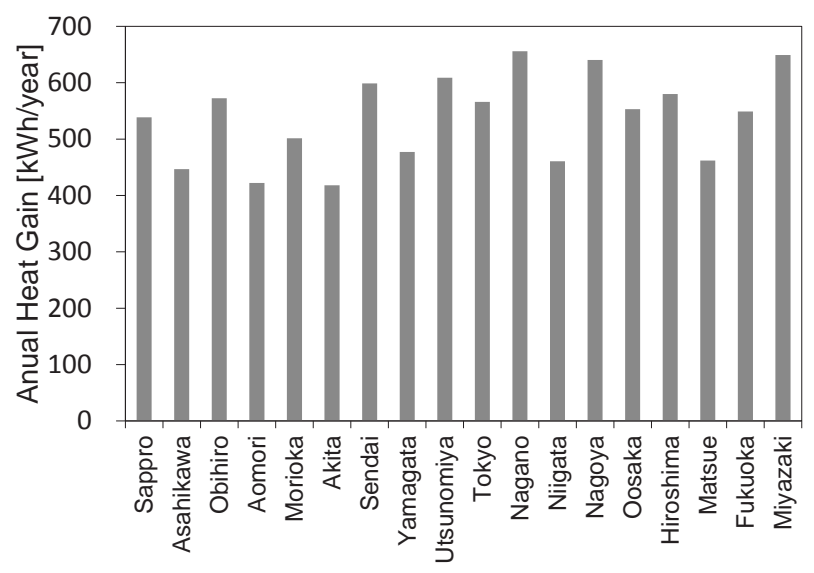

Fig.18 Calculated annual heat gain

\section{7. おわりに}

設備投資費用対効果の高い壁付け太陽熱集熱パネルを対象に、基 本性能を実験的に明らかにし、供給熱量簡易予測シミュレーション 手法を構築した。また、その精度を検討するとともに、全国の代表 的な地域における集熱効果予測を行った。本研究により得られた知 見を以下に示す。

1）対象集熱パネルの送風性能や日射透過性能を実測により明ら かにし、その構造に応じた集熱量予測の簡易式を提案した。

2）アメダス気象データの全天日射量で、容易に直散分離が行う事 が可能な本研究モデルを提案し、既往モデルの Nagata モデル と Perez モデルの 2 モデルを比較対象とし、2000 年版標準年 EA 気象データを用いて理論計算と比較した。大気透過率、法 線面直達日射量、水平面天空日射量、南鉛直面の入射日射量そ れぞれにおいて高い相関関係が見られ、十分近似值が得られる ことを示した。

3）実験装置を用い、本研究モデルと実測の比較を行い再現性の確 認を行った結果、本研究モデルで推定集熱量が再現できること が確認出来た。

4）北海道千歳市の実住宅に対象壁集熱パネルを設置し、提案した 本研究モデルを適用した予測値と実測值を比較した結果、よく 一致し、実用上十分な精度で計算可能である事を明らかにした。

5）本研究モデルで全国 18 都市の年間集熱量の予測を行い、暖房 期間の集熱量で $420 \sim 650 \mathrm{kWh}$ の年取得集熱が全国の各都市で 期待できることを示した。

今後、当該太陽熱集熱パネルの暖房負荷低減効果を高める手法の開 発や、非暖房期の有効利用に関寸る研究を進める予定である。

\section{謝辞}

本研究にあたり、東洋大学名誉教授 土屋喬雄氏には多大なるご 指導を頂きました。記して感謝の意を表します。

注

注1） $\mathrm{M}_{\mathrm{B}}$ ：「周囲部材の熱容量の一部」の $5057 \mathrm{~J} / \mathrm{K}$ については、 5 章におい て行った実測と計算との誤差が最小になるように、最小二乗法でその 值を求めた。

\section{参考文献}

1) New Energy and Industrial Technology Development Organization: Guideline for introduction of industrial solar thermal utilization of system of F.Y. heisei21

http://www.enecho.meti.go.jp/category/saving_and_new/attaka_eco/r eference/pdf/donyu-kento/donyu-kento.pdf, (accessed. 2016. 05. 03) 独立行政法人新エネルギー・産業技術総合開発機構：平成 21 年度業務 用太陽熱利用システムの導入検討ガイドライン，

http://www.enecho.meti.go.jp/category/saving_and_new/attaka_eco/r eference/pdf/donyu-kento/donyu-kento.pdf, 平成 21 年 12 月, （参照 2016. 05.03)

2) Hitomi. MURAKAM, Kengo. KITAMORI : A questionnaire survey on home owners' interest in solar water heaters in Ube City and use in disaster. pp597-600, 2013. 05 村上ひとみ, 北森健吾 : 太陽熱温水器の普及実態と関心度に関する宇 部市での調査と震災での活用例、日本建築学会近畿支部研究発表会, 第 53 号 pp597-600, 2013.05

3) Institute for building environment and energy conservation : Building research institute(Independent administrative institution), Design guidelines for low energy housing with validated effectiveness : Mild climate region edition, pp102-111, 2015. 08 財団法人環境建築・省エネルギー機構：国土技術政策総合研究所・独 立行政法人建築研究所監修「温暖地版自立循環型住宅への設計ガイド ライン」, pp102-111, 2015. 08

4) Hiroshi. K, Youngjin. C, Kozo. T, Makoto. S, Hyunwoo. R, Katsuya. O, Masayuki. M, Seiji. K : A study on the improvement of system performance in the residential building using air-based solar heating system, Proceeding of annual meeting, The society of heating, air-conditioning and sanitary engineers of Japan, 2013. 09 北潟寛史，崔榮晋，高瀬幸造、佐藤誠，盧炫佑，小原克哉，前真之， 駒野清治 : 空気式太陽熱集熱暖房方式を利用した住宅のシステム性能 改善効果に関する研究, 空気調和・衛生工学会大会学術講演論文集 2013. 09

5) Miyazawa. C, Kurayama. C, Tashiro. T, Saio. R : Evaluation of solar collecting boards on equal terms. Part 1: Outline of measuring instrument machine, device and specimen. Part2: Result of experiment by the solar simulator. Part3: Current of air onfirmation, Comparsion with field test, Summaries of Technical Papers of Annual Meeting, Architectural Institute of Japan, D-2, pp117-122, 2008. 07

宮沢千顕，倉山千春，田代辰一郎，齋尾梨沙：太陽熱集熱板の横並び 性能評価その 1 測定機器、装置及び試験体概要, その 2 屋内測定結 果, その 3 気流確認及びフィールドテストとの比較, 日本建築学会大 会学術講演梗概集，D-2,pp117-122，2008.07

6) Zushi. M : Performance evaluation of solar air collectors with perforated metal panel, Summaries of Technical Papers of Annual Meeting, Architectural Institute of Japan, D-2, pp487-488, 1999. 09 図子正志 : 金属多孔板を用いた空気式太陽熱集熱器の性能評価, 日本 建築学会大会学術講演梗概集，D-2，pp487-488, 1999. 09

7) Koganei. M, Kashiwase. Y: Experimental study on solar extemal wall, Summaries of technical papers of annual meeting, D-2, pp459460, 2000. 09

小金井真, 柏瀬芳昭 : 太陽熱集熱外壁材に関する研究, 日本建築学会 大会学術講演梗概集, D-2, pp459-460, 2000. 09 
solar heating system, Journal of Environmental

Engineering(Transactions of AIJ), No.582, pp42-52, 2004. 08

北野博亮, 相良和伸 : 空気集熱式太陽熱暖房システムの簡易設計法に

関する研究, 日本建築学会環境系論文集, 第 582 号, pp45-52, 2004. 08

9) Hiroaki. K, Kazunobu. S: Theoretical approach to optimum volume of rock bed for air-based solar heating system, Journal of Architecture, Planning and Environmental Engineering (Transactions of AIJ), No.532, pp29-35, 2000. 06 北野博亮, 相良和伸 : 空気集熱式太陽熱暖房システムの最適蓄熱槽容 量に関する理論的検討, 日本建築学会計画系論文集, 第 532 号, pp2935, 2000. 06

10) Kenji. N, Toshiyuki. W, Tetsuo. H, Yuji. R, Yasunori. A: Guidline of plan of solar house with solar air collector and floor heating system, Journal of Architecture, Planning and Environmental Engineering (Transactions of AIJ), No.516, pp31-38, 1999. 02 中村健児, 渡辺俊行, 林徹夫, 龍有二, 赤司泰義 : 太陽熱利用空気集 熱式床暖房住宅の設計指針, 日本建築学会計画系論文集, 第 516 号, pp31-38, 1999. 02

11) Yuta. F, Ryutaro. K, Koji. S, Osamu. I: A study on the system with solar thermal use with solar air collector. Part1: The heat collection efficiency and performance of the system in winter, Proceedings of AIJ Kyushu chapter architectural research meeting, No.46, pp117120, 2007. 03 藤岡雄太，久保隆太郎，酒井幸司，石原修：空気集熱式太陽熱利用シ ステムに関する研究 その 1 集熱パネルの集熱特性と冬期実測による システムの性能解析, 日本建築学会九州支部研究報告, 第 46 号, pp117-120, 2007. 03

12) Mitsuhiro. U, Makoto. S, Hyunwoo. R: Simulation of roof integrated solar collector for space and DHW heating systems. Part1: Simulation model, Part2: Example results pf space and DHW heating system for residential house using solar air collector, Summaries of Technical Papers of Annual Meeting, Architectural Institute of Japan, D-2, pp1145-1148, 2009. 08 宇田川光弘, 佐藤誠, 盧炫佑 : 屋根一体型太陽熱集熱暖房・給湯シス テムのシミュレーション その 1 計算モデル、その 2 住宅における空 気集熱暖房・給湯システム計算例, 日本建築学会大会学術講演梗概集, D-2, pp1145-1148, 2009. 08

13) Go. I, Hideto. K, Kazunobu. S: Study on performance estimate of solar house. Part1: Outline of experimental house and some measured results, Part2: System COP and thermal storage condition, Summaries of Technical Papers of Annual Meeting, Architectural Institute of Japan, D-2, pp417-420, 1996. 09 岩田剛, 久保秀人, 相良和伸 : ソーラーハウスの性能評価に関寸る研 究 その 1 実験住宅の概要と実測結果,同題, その 2 システムの成績係 数と蓄放熱について, 日本建築学会大会学術講演梗概集, D-2, pp.417420, 1996. 09

14) Institute for building environment and energy conservation : SMASH for windows Ver.2, 2000 財団法人環境建築・省エネルギー機構：SMASH for windows Ver.2, 2000

15) Meteorological data system Co.,Ltd: Technical description [Calculation of separating direct and diffuse insolation on a horizontal surface and prediction of insolation on tilted surfaces], http://www.metds.co.jp/wp/wpcontent/contents/documents/technical-writing/tyokusan.pdf, 2014. 07. (accessed 2016. 05. 20) 株式会社気象データシステム: 技術解説「直散分離と斜面日射量の計 算」http://www.metds.co.jp/wp/wpcontent/contents/documents/technical-writing/tyokusan.pdf, , 2014. 07, (参照 2016. 05. 20)

16) Tanaka. S, Takeda. H, Iwata. T, Tsuchiya. T, Terao. M, Akimoto. T: New building environmental engineering, pp206-207, 2015. 02 井上書院 : 最新建築環境工学 改訂 4 版, pp206-207, 2015. 02

17) Tanaka. S, Takeda. H, Iwata. T, Tsuchiya. T, Terao. M, Akimoto. T: The Lates Engineering of Building Environment, p208, 2015. 02 


\section{CALCULATION METHOD OF SUPPLY HEAT QUANTITY \\ FOR A SOLAR HEATING PANEL MOUNTED ON EXTERNAL WALL

\author{
Junichiro MATSUNAGA ${ }^{* 1}$, Akira FUKUSHIMA ${ }^{* 2}$ and Masaki TAJIMA ${ }^{* 3}$ \\ ${ }^{* 1}$ Matsunaga Co., Ltd \\ ${ }^{* 2}$ Prof., Hokkaido University of Science, Dr.Eng. \\ *3 Assoc. Prof., Kochi University of Technology, Ph.D
}

Pneumatic solar collector systems have a certain advantage of conversion efficiency of $40 \%$ to $60 \%$ and less long-term failure compared with liquid types. However, according to previous studies, pneumatic solar heating systems require large power input for air supplying and sometimes provide overheating and overdrying.

In this paper, utilizing a heat collecting panel working as an auxiliary heating facility, which is consist of simple devices and requires no power source, a prediction method of heat collection effect especially for energy saving design of houses is shown. Experimentally the panel's basic performance is clarified and a simplified separation method of normal direct solar radiation and horizontal sky solar radiation for predicting the heat collection amount in various places in Japan by using the total solar insolation of the AMeDAS meteorological data is also shown. The calculation results of heat collection amount obtained by the present works' separation method is evaluated by comparing to experimental results and the other separation method given by previous studies and concluded its practicality. Moreover, heat collection amounts of the representative area in Japan are shown.

The followings are the results and findings of this study.

1) A simplified formula of heat collection amount prediction of the solar heating system, which is validated by experimental result, is proposed.

2) A unique separation model of normal direct solar radiation and horizontal sky solar radiation is shown and concluded its practicality by comparing to the Nagata Model and Perez Model.

3) Using an experimental equipment, the reproducibility of calculated supply heat quantity using present work's method is confirmed.

4) Using the wall mounted solar heating panel installed in a real residence in Chitose City Hokkaido, the predicted heat collection amount and actual measured value are compared and conclude that, they are in good agreement and can be calculated with practically sufficient accuracy.

5) By using proposed model, heat collection amounts in 18 cities in Japan are calculated and the results show the annual heat collection is approximately 420 to $650 \mathrm{kWh}$ in the heating period can be expected in each city. 